\title{
Characterising the Principles of Professional Love in Early Childhood Care and
}

\section{Education}

\author{
Jools Page \\ University of Brighton
}

\begin{abstract}
Framed as an extension of Noddings' notion of the 'ethic of care,' the paper sets out an argument about 'Professional Love' as both a term to comprehend the reciprocal pedagogic relationship which develops in positive interactions between primary caregiver, child and parent and as a core normative component of early years educational discourse; the paper grounds this conceptualisation of Professional Love in attachment theory (both its empirical validity and its sociological shortcomings); it then posits the dynamic of child-parentpractitioner love as a Triangle of Love which is essentially complementary to the parent/child relationship as opposed to representing any risk or threat to parents' relationships with their children. The paper examines the work of theorists of care who have been particularly influential in developing the notion of Professional Love, and it considers the work of interdisciplinary scholars whose challenges to notions of love and care help problematise and clarify Professional Love beyond romanticised or other contextually inappropriate forms of love. The paper is intended as a provocative and explorative piece of critical enquiry; it highlights the prevalent devaluation of care/love in policy making and posits a semioperationalisable prospectus for cultivating Professional Love in early childhood settings. Consistent with the author's editorial foreword, tensions between practitioner, child and parent, as well as internal encumbrances placed on practitioners to develop Professional Love in the absence of policymaker support, emerge as recurring themes.
\end{abstract}

Keywords: Professional Love, Relationships, Pedagogy, Infants/Toddlers, Early Years Practitioners

\section{Foreword}

The immediate purpose of the paper is to answer some of the questions which I have met within my research and teaching, and so to clarify - for myself as much as for others - what might be meant by the notion of Professional Love. In using the term Professional Love, I want to indicate a quite particular discourse of which early years professionals should be expected to articulate; a set of practices which I would expect to see implemented in early years settings; and, thirdly, a culture of open, collaborative and reflexive enquiry in the early years setting.

\section{Introduction: characterising Professional Love}

A conceptual model which characterises Professional Love in order to distinguish 'healthy' and consciously-informed practices from those which may put children at risk of harm 
foregrounds this paper. Attachment-based studies highlighting in particular the significance of Bowlby's Internal Working Model (Bowlby, 1973) are presented hereafter; attachment theory is argued to reinforce the importance and legitimacy of Professional Love both because it de facto evidences the importance of intimacy and bond-formation and, conversely, precisely because of attachment theory's failure to factor in the range of variable and carer agents whom the child is connected to and surrounded by; this failure to account for the socio-cultural complexity of childhood is suggestive of the need for Professional Love to be developed as a core discursive concept. The main tenants of Bowlby's Attachment Theory (Bowlby, 1953) are central to the primary caregiving role which English early years policy and practice confers on a primary caregiver ${ }^{1}$, known as the key person, and refers to the organisation of this as the key person approach (DfE, 2017). Nevertheless, there are a multitude of definitions of love. Gratzke (2015), researching contemporary representations of love, claims that 'love is what people say it is'; but he qualifies it thus:

'Love is what people say it is', means in a phenomenological sense that people's lived experiences and descriptions of love should be taken seriously by love researchers. Love is what people describe it as being

(Inaugural speech, Love Research Hull 2015)

Taking Gratzke's (2015) point into the realm of early childhood it would seem fair to suggest that 'love is situational'. In other words, love is 'situated' in an early years setting: it is situated in the complex lives, experiences, attitudes, feelings, histories of everyone who participates in a setting. Love has an operational meaning. It is how it is done, and by whom, and why, where and when, and with what effect. The 'furniture of love', refers to the furniture of people's experiences which can only come about if those in society who have a role to play in the lives of young children can debate the 'hard stuff'; to tackle the emotional complexities which are bound up in these intimate relationships; to create, that is, a 'phenomenology of love' within the early years setting.

Theory and practice are not separate entities for society-as-lived. Employing a theoretical framework to understand the complex narratives which are part of everyone's life can help to begin to make sense of how love can and does manifest itself within professional roles with young children in their early years settings, rather than denying - in varying shades of horror its existence altogether. There is an assortment of theories which can be applied to taking hold

\footnotetext{
${ }^{1}$ I use the term primary caregiver to refer to either the main carer at home or the professional adult in the early years setting who works in a primary attachment role with the child.
} 
of love so as better to view it, and these are rooted within a range of disciplines (only some of which are discussed here, e.g. attachment theory).

I subscribe to the view that love is evolutionary in nature; that there is freedom to evaluate love from within a range of philosophies rather than suggesting love should be situated within a specific theoretical standpoint or analytical discipline. Professional Love is a complex construction because there are many instances when aspects of love, intimacy and care are overlapping and cannot be compartmentalised, which is why it is difficult to distinguish these - one from another - within actual professional early years practices in any tangible way.

\section{Attachment Theory: grounding Professional Love in experimental psychology}

Attachment based studies by John Bowlby and Mary Ainsworth, relying on a peculiarly Western view of relationships (as attachment-forming, discreet subjects discreet from but emotionally dependent on one another), have been central to debate since their publication in the 1950s and 1960s. Bowlby's theories of attachment were developed from his observations of children in hospital who had been separated from their mothers. Based on the findings of this research and on his earlier studies of delinquent children, Bowlby (1969) claimed that the child flourished best when he or she was in the company of a primary caregiver - with whom the child had formed a sensitive relationship - with the ability to provide the child with comfort and security in times of distress; usually this was with the mother. Bowlby proposed that the infant needed to develop an Internal Working Model (IWM) which represented the 'self', 'the other' and also a model of the relationships between the self and the other (Bowlby, 1969, 1973, 1988). Bowlby claimed infants draw upon the IWM to know what to expect when faced with new and potentially threating situations. Thus, if a child's need for comfort had been reliably met by a sensitive caregiver i.e. the mother, it is the memory of this experience which the child draws upon in times of future distress and which can keep the child's feelings 'contained' (Bion, 1962) in the knowledge that his or her bids for attention will be attended to.

If, on the other hand, the child's needs have not been reliably and consistently met by a sensitive caregiver, then the child's IWM will not be able to predict what will happen on future occasions. This may in turn serve only to fuel his or her anxiety and distress when faced with, for example, separation from a trusted and available adult. Bowlby's protégé, Mary Ainsworth, carried out studies with mothers and infants in Uganda (Ainsworth, 1963) and later in Baltimore (Ainsworth, 1967) in a bid to understand the relationship formations of these motherchild dyads, drawing from Bowlby's theories. The findings informed Ainsworth's ideas about 
the need for the child not only to be securely attached to the mother but also for the mother to act as a 'secure base' from which the child could safely explore his/her surroundings.

\section{The limitation of attachment theory: a Paradoxical defence of Professional Love}

Nevertheless, Attachment Theory has been heavily criticised not least by scholars who have argued that Western dominated views of attachment undermine the structure of families in the global south. Quinn and Mageo (2013) claim that attachment-based models of childrearing can undermine communities of practice in non-westernised contexts that subscribe to alternative methods of raising their young children. Yet, as McHale (2007) points out; 'the dominant theory in infant mental health and indeed, in all psychological accounts of socioemotional development, remains the dyadically based attachment perspective' (p.372). Thus, it is unsurprising that these theories continue to dominate the discourse within early childhood education, especially amongst infant/toddler protagonists (Elfer, 2006; Dolby et al., 2014). McHale (2007) claims that although an infant's relationship begins with the mother, in 'multiperson relationship systems' (co-parenting dynamics for example) there are a range of complexities surrounding the child which need to be taken into account, not least whether the parents are in a harmonious relationship with one another or not and the impact of this on the child. McHale (2007) argues the case for professionals (clinicians in this case) to consider family intervention strategies which look beyond the mother-child dyad and which assess the roles played by members of the wider 'family' which may also include caregivers who are unrelated.

Situated within a discussion of the Kindergarten movement, Aslanian (2015) argues that following the rise of scientific rationalism in Western society in the $19^{\text {th }}$ century which privileged reason over emotion, such behaviourist-positivist models have shaped the contemporary discourse on love and care in early childhood education. Drawing on the work of Bloch (1992), Aslanian (2015) claims that as behaviourist theory proliferated within the psychological domain from its nascent form in the early 1900s, childrearing became a hot topic of debate which not only criticised how mothers intuitively responded to their children but also heavily influenced the early childhood educational domain. The notion of spoiling the baby by attending to their bids for attention was popularised and frowned upon, in favour of enforcing a distance between the child and the parent/carer.

Behaviourist theories at this time represented an extreme version of scientific rationalism. The unseen was truly unaccounted for. When these theories were applied 
to child care, a new discourse of care emerged. The degree to which science took precedence over matters such as love, which were not 'observable', is illustrated in Watson's advice about children that parents should 'never hug and kiss them, never let them sit in your lap (Watson, 1928, p. 81 in Bigelow and Morris, 2001, p. 27)'

(Aslanian, 2015, p.160 emphasis in the original)

Aslanian (2015) suggests that Bowlby's work attracted credit because at the time of publication there had been a shift in societal views away from an intuitive and loving model of childrearing and teaching with love, as advocated by early years pioneers such as Montessori, Pestalozzi and Froebel, towards a more scientific approach; this later proved catastrophic for sick children in hospital who were starved of affection, and heralded the World Health Organisation to commission Bowlby's original review of maternal studies. Within the early years discourse, because love is intangible, it has lost traction, intuition has been discredited, replaced instead by a reliance solely on understanding children from a behaviourist perspective. In light of Aslanian's argument it is easy to explain why Bowlby's theory of attachment held such currency because it not only refuted scientific rationalism and its epistemological precepts, but more importantly it brought the role of the mother-child dyad and intuitive relations sharply back into forensic focus.

In their examination of infant toddler relationships in early years settings, Degotardi and Pearson (2009) caution against overemphasising attachment theory. They claim that although there is evidence to sustain the notion of how long it takes to develop relationships (Cassidy, 2008) that studies have not sufficiently investigated the basis on which these relationships are created and developed. Degotardi and Pearson (2009) argue therefore that if early years practitioners become too consumed with primary caregiving, that this restricted lens fails to take into consideration competing theories (Stern, 2000; Dahlberg, Moss and Pence, 2007) which call for attention to be given to children's innate desire for exploration and playful interactions with their peers as well as with other adults beyond their primary attachment figure; this theoretical constraint can inhibit children's learning.

White (2016) argues that over-emphasising relationship theory is a risky business because it suggests there is a universal definition of love which obscures many culturally contextualised models. Infants and young children do not live in isolation, therefore the contentions of McHale (2007), Degotardi and Pearson (2009) and White (2016) are noteworthy contemplations for when children are forming relationships in early years settings. However, in spite of its 
chequered past, attachment theory does help to explain why young children thrive most when they are in the company of adults who are genuinely interested in them and who are able to form strong, attuned, attachment relationships with them (David et al., 2003). It is vital to point out that children who are securely attached and who have a secure base (i.e an adult upon whom they can rely and return to in times of distress) will be better disposed for exploration and learning than a child who is insecurely attached. In an early years setting if the key person ought to be the child's 'attachment figure', as policy dictates, then it is reasonable to expect that the key person will become invested in the child, and, over time will form a loving, relational bond with the child. Yet, unlike, for example, in social work, the complexity of this professional attachment relationship has not been addressed within early years discourse.

Attachment theory, then, both validly highlights for early years discourse and practitioner values, the importance of Professional Love in encouraging a Triangle of Love between parent, child and early years practitioner and, simultaneously alerts us to the stark limitations of behaviourism and culturally specific interpretations of love. In its facilitative role as an empirical and theoretical justification of Professional Love, attachment theory grounds my argument that Professional Love can and does enhance (child) learning and development, emotionally and cognitively. This is because Love in its myriad forms is, according to the evidence from attachment studies, central to those areas of development.

Child learning and development, as well as early years learning environments and cultures, can be enhanced by imbuing early years discourse with the nomenclature of Professional Love. I proceed to argue that Professional Love can enact this enhancement via the fostering of a Triangle of Love which forms between and across child, parent and practitioner. The Triangle of Love is in essence complementary to and facilitative of the parent/child relationship, as opposed to representing any risk or threat to parents' relationships with their children. It is reciprocal and tripolar in its causal flows, with parent/practitioner Professional Love nurturing a secure attachment in the child, free of internal conflicts, with child/parent relations securely based and mutually reinforced by the practitioner, and with practitioner/child interactions and intimacy serving to buttress the familial love provided by the parent. The inter-causal dynamism and complementarity of the Triangle of Love remain as normative ideals in practice, policy and discourse; because (as discussed below) the Triangle of Love is a utopian abstraction, and because it is rarely if ever fully achieved in practice and effect, it is intended as a normative "ideal type". Nevertheless, the argument here is that attachment theories justify 
the inclusion of Professional Love in popular and academic discourses pertaining to early years studies, and - at the same time - raise issues from their own limitations (as discerned by social work theorists) which indicate that the crudity of mother-focused and Western-centric models of attachment formation can be redressed in part by the inclusion of Professional Love as a conceptual language. Bowlby's and Ainsworth's works, it must be noted, highlight the brute reality of insecure attachment on-the-ground for many children. The story of Shelley (below) offers a narrative glance at the effects which ensue from a dearth of Professional Love. This story highlights the ways in which the interplay between practitioner, child and parent can go awry in such a way as to atrophy the fostering of Professional Love:

\section{A Dystopian Triangle: Shelley}

In this (dystopian) vignette, 3-year-old Shelley (an anonymisation) embodies a case in which love is 'hard-fought for against institutional and parental resistance'.

I remember reading a book, years ago, about respecting all children, not just those who are 'easy to work with, obliging, endearing, clean, pretty, articulate, capable...'(Nutbrown, 1996, p.54) and if ever there was such a case it was Shelley, who the nursery staff immediately and uniformly 'struggled' desperately with how to meet her emotional needs. This was partly because they knew Shelley's family (on the estate where they all lived). At 3 years old, Shelley was considered small for her age, still spoke in 'baby' language and was not out of nappies; these were nearly always soiled and her clothes unchanged on arrival at nursery. She was aggressive with all other children, who quickly learned to steer clear of her, and so she became used to getting her own way (and often with staff too, who wanted to avoid one of Shelley's screaming, biting, kicking tantrums. ...). The effects on the staff were all negative, and they seemed to make Shelley's recalcitrance worse by oscillating between compliance with her whims and indifference toward her which seemed to remind her of her home life because anything other than 'getting her own way' from staff would invoke a highpitched squeal, accompanied by more kicking and punching. When Mum or Aunty arrived in the evenings, this indiscipline on the part of the staff - their unwillingness to be consistent for the child - now took its toll on the family's relationship with the nursery; Shelley played one against the other, reporting the staff's disregard for her in a tell-tale voice, or, alternately, sniping at her Mum that the staff are 'much nicer than her'; sometimes both. Over time, Mum increasingly delegated pick-up duties to the Aunt, who was less vocal in her competition with the staff for Shelley's affection and popularity. Shelley suffered, we suffered, the family 
suffered... Nobody related to the other in a way that put them in the others' shoes. Everyone stuck to their guns and protected their interests; Shelley became more withdrawn than proactively chaotic after a while. I think she began to feel that she was stuck in the middle of something that was not working out.

\section{Drawing from caring relations theory: the emotional labour of fostering professionally loving practice}

In 1984, Noddings set out her ethic of care as a relational and inter-subjective activity, rather than as care-given by the care-giver. I have discussed elsewhere Noddings' theorisation of caring and how this fits with my own framing of Professional Love (Page, 2011, 2013a, 2013b, 2013c, 2014, 2016). I note here that much of Noddings' theorisations of care, as well as those of Pettersen $(2011 ; 2012)$, emphasise the feminisation of care and the conceptual-normative defining of care work as fundamentally "women's work"; there is a vast literature pertaining to this topic, also directly relating to early years education, but this argument is purposively placed outside the scope of this paper; I focus, instead, on the relationality of care /early years practice which arises from these works. Noddings' (2003) conceptualisation of caring relies on the human subject being in a relationship with another which is distinctive because it contrasts with the view of caring as a subject-object act.

In moral reasoning studies carried out by psychologist Carol Gilligan (1982), it is claimed that maturity plays an important role in understanding the self in relation to others. In the caring professions, Pettersen $(2011,2012)$ takes this debate further. In nursing for example, Pettersen (2012) argues that Gilligan's (1982) notion of 'mature care' provides a model of understanding whereby the carer gradually comprehends the care needs of the self, as equally important to those of the cared-for. Thus, the needs of the 'cared-for' are not always privileged over the needs of the carer - this is significant in caring roles because it dispels the perception of altruism in caring and refutes the notion of selfishness in seeking support for work in emotionally taxing roles. Pettersen's (2012) view of reciprocity aligns with Noddings' (2003) position on caring relations, whereby she maintains that 'caring is a relationship that contains another, the cared-for, and we [sic] have already suggested that the one-caring and the cared for are reciprocally dependent' (Noddings, 2003, p.58).

It is no leap of logic to argue that this is patently the case in early years settings. The early years practitioner receives emotionally intensive and normatively meaningful experiences of 
attachment to the child s/he works with; the mature care model suggests that this is not a pedagogical failure, but in actual fact a driver of more effective practice. By engaging in a relationship with the child, moreover, and not merely acting onto the cared-for, the early years practitioner serves to reinforce the formation of secure attachments in the child and acts as a model for the development of healthy and meaningful relations in the child's present and ongoing lifespan.

As Goldstein (1998) points out, the challenge for early years practitioners is to resist the narrative which implies that caring is easier to perform and requires less intellect than traditional forms of teaching in education (see also Shin, 2015; Rockel, 2009). The intuitive approach to working with children in professional settings is undervalued and debunked in the contemporary discursive field of early years education (Aslanian, 2015). Noddings states that:

People usually identify care with care-giving... though, you have to be careful, because I do not equate care and care-giving. This is wrong, because care-giving as an occupation can be done without care.... You can go through the motions of care-giving without really caring and without [the person cared for] receiving the care...

(in Kawamura, 2013, p.4)

This quote from Noddings supports my argument as to why young children crave relationships with adults who understand them and who will not reject their bids for attention, i.e. babies and young children need care-givers who will 'listen' and who are able to 'tune into' them in a multitude of ways. This is not because these adults are paid to care-give but because they are compelled to respond with care and eventually with love that is formed over time within the context of closely attached relationships. In keeping with Pettersen's $(2011,2012)$ articulation of Gilligan's (1982) notion of mature care, the 'carer' must also have their own needs met and thus the relationship must be mutually beneficial and come to be recognised as wholly reciprocal. Reciprocity therefore, can only exist when the infant or young child accepts the adult into their lived experience and thus the adult, the one-caring, is in relation with the child.

In an early years setting, whereby the adults hold the most 'power', there is potential for disproportionate imbalance within adult-child relationships which is a hotbed for professional and parental caution, anxiety and fear (Page, 2011, 2016, 2017). Yet, this myth about caring as being somehow less consequential than cognition has been continually perpetuated in relation to working in early years, certainly in England, where less attention has been given to the pay, 
conditions and qualifications of early years practitioners who choose to work in caring roles in education, especially when working with infants and toddlers (Shin, 2015; Powell and Goouch, 2012). This devaluation of Professional Love encumbers the individual practitioner with the task of developing a Triangle of Love; managers, policymakers and politicians have not, thus far in England, done their bit to facilitate a substantive framework for practising Professional Love.

\section{The devaluation of love: policy as an encumbrance on individual practitioners}

In her independent review of early education and childcare qualifications in England, Nutbrown (2012) said: 'It is absolutely essential that we have high quality practitioners working with babies and young children' (p.35). She further argued for a career in early years to be given proper status by increasing the standard of entry on initial early years training programmes. Nevertheless, in spite of Nutbrown's argument, there is still an underlying tension about the place of caring in early years practice. Nutbrown claims there is a 'misconception' about the challenges of working as an early years practitioner and referring to her call for evidence said:

Some appear to think that working with young children means nothing more than changing nappies and wiping noses. This is a misconception of what it is to work with young children and an insult to young children themselves whose needs are as important and complex (if not more so) as those pupils in the later years of schooling.

(Nutbrown, 2012.p.15, my emphasis)

I note here that although Nutbrown (2012) is a staunch advocate for high quality early education, as evidenced in her review, there is an implicit position in this text that wiping noses and changing nappies (a caring role) is unimportant. Moreover, because 'wiping noses' is regarded as a perfunctory task, as opposed to an intellectual and professionally loving care encounter, it can be carried out by 'anyone' (Lally, 1995), whereas for infants and toddlers in particular the exact opposite is the case. As Goldstein (1998) points out 'caring for children is both an emotional and intellectual act, and as such, forms a legitimate foundation on which to build an early childhood curriculum' (p.259). Caring relations are not new phenomena for discussion within early education. Nevertheless, critics of maternal care and attachment theory have contributed to the uncertainty surrounding the place of feelings and emotion in professional early years work. Turning more broadly to the practices of health and social caring professions (Ferguson, 2017; Pettersen, 2012) provides a vantage point from which to situate our understanding of the emotional complexity of reciprocity within early years discourse. 
Pettersen's (2012) emphasis on maturity as the ability to take the interest of both the self and the other into perspective is helpful. I advocate therefore that there is scope to introduce a framework of developing Professional Love practice into early years discourse to take account of the differentiated steps required to fully comprehend the place of self-reflection as a first step in the process toward realising Professional Love. This framework of support would be achieved within initial early years syllabi as well as in continued professional development programmes that sit alongside the development of supervision practice (Elfer, 2012).

Policy cultures and processes constrain the establishment of Professional Love as a credible and valuable concept for early years education because the qualifications frameworks, the content of formal training and the nature of continuing professional development are infused with the notion of care as care-giving. The onus in this scenario comes upon the individual practitioner to engage in the emotional labour of reflexively developing a Professionally Loving approach to the child; yet s/he does this over and against the tidal wave of policy discourse which frames and defines his/her role as that of a (devalued and) detached giver-ofcare.

Policy making in early years education is enmeshed and infused with the common-sense notion of care as care-giving. Pettersen states that:

The conception of [care as] selflessness holds the idea of forsaking one's own interests for those of others either by overriding them or by providing care to the point of selfsacrifice. From a philosophical perspective, selflessness is problematic. Why should the cared-for's interest consistently weigh more than the carer's interests?

(Pettersen, 2012, p. 369)

Policymakers' sequestration of Professional Love from practitioner discourse serves to burden the individual practitioner with an injunction to sacrifice and sequester his/her needs in an emotionally laborious way that is arguably unrealistic and deeply challenging. Consistent with my argument that policymaking and policy officials need to invoke and use the lexicon of Professional Love in the "hard" curricula of their early years training programmes, we need to create spaces of learning for early years practitioners which allow them the time and which spur their emotional energy, such that they can include aspects of loving in their practice (Elfer, 2012). 
If policy intervention is limited to words in textbooks and not conscious learning then the danger remains that the carer-practitioner is overburdened with an asymmetric and disproportionate degree of responsibility to practice Professional Love if the policy package only intervenes by introducing the mere words and signifiers of Professional Love into the training environment and deliberation (Pettersen, 2012). As Cousins (2017) notes of the practitioners in her study:

Some ECEC practitioners do not show children that they are loved as naturally as others. It would be useful if they could be helped and supported to undertake this aspect of their role better. Possibly initial training should include content about the importance of loving children and showing them that they are loved

(Cousins, 2017, p.27)

\section{Teaching with love; touching with caution; kissing in fear}

Based on a number of studies conducted in Finland (2011, 2012a, 2012b,2012c,2012d, 2013) Uusiautti and Määttä (2013) claim that 'love-based leadership in early education is a method that renews teachers' professional skills' (p.109). The authors argue that providing an appropriate environment for children to learn and for practitioners to see the child's perspective are the hallmarks of teaching with love. They suggest the need to engage with a discourse on love against the backdrop of raised awareness of well-being and happiness which are becoming popularised within educational disciplines:

Basically, love-based leadership in education is considered a working method that involves persistent interest and perseverance to support pupils' development for the sake of themselves and the whole society (Uusiautti and Määttä, 2013, p.114).

The extensive interest in love in early childhood education within the Finnish context could be attributed to the statutory recognition in national policy of care and education as being equal in status. Thus, a pedagogy of love (Darder, 2002; Uusiautti and Määttä, 2013, Määttä and Uusiautti 2013) holds evaluative currency within the Finnish educational domain because a shared narrative exists about the need to ensure all children know and understand that they are worthy of being loved (Page, 2014); this provides a basis for emotional resilience, for learning and ultimately for independence. There is a significant gap in the English early years system about the places of love, care and intimacy and such terms are often shrouded in language such as building a 'positive relationship' as opposed to a 'loving' one. In fact, the words 'loving' and 'secure' have been sequestered completely from recent iterations of early years policy in 
England (DfE, 2012; 2014; 2017) which indicates that love does not exist in the public lives of children outside of the private sphere of home and family; if it does it is somehow taboo.

Page and Elfer (2013) and Elfer and Page (2015) have attempted to understand how national and local policies which call for practitioners to form close attachments with babies and young children in their early years settings are implemented. In the first of those studies, they report employing a range of methods (including solicited diaries, and individual and focus group interviews) to determine how a children's centre implemented the key person approach at just the point at which it became a mandatory requirement within the English policy framework (DCSF, 2008). Although attempts had been made by the centre management tiers to create policies which took account of the varying ages and needs of the children, there was a sense of complexity which became apparent during the data analysis.

Overall, the study found that the staff used a largely intuitive approach to managing their own emotions and those of the children. In spite of their best intentions it was impossible for the staff to maintain consistency of attachment - which the data confirmed they 'knew' only too well - that young children need if they are to be able to feel secure and settled. (This also links back to the story of Shelley above.) There is, then, a distinct dearth of clarity, guidance, definitional standards and operationalizable norms surrounding Professional Love in early years settings. An iterative and provisional exercise in redressing this dearth and plugging these ideational gaps is engaged in throughout the proceeding section.

\section{'Thinking about Professional Love'}

Figure 1 - 'Thinking about Professional Love' - represents the Triangle of Love which, over time, is developed and continues to evolve between parent, child and practitioner. Professional Love builds on Noddings's (2003) 'ethic of care' where there is a compulsion on behalf of one person to care for the other. When reciprocity exists, and as the relationship deepens, then the compulsion to care, together with the capacity to de-centre and invest a level of emotional intimacy into the relationship, can it be characterised as Professional Love. It is the shared understanding that adults can bring to the experience for the child, which can, over time lead to a strong, secure attachment because in effect the parent is acknowledging, accepting and permitting Professional Love. Mutual agreement emerges between parent, child and practitioner through direct verbal communication, whereby care and love are seen as viable and credible aspects of the education of the child in question, as well as through less direct, 
unspoken communicative media such as via official childcare mission statements and organisational publications, It is when mutual agreement in the form of an unwritten 'permission' ( Page, 2011) does not exist, or if the practitioner becomes over involved with the child, that the capacity for tension and unease, which can lead to emotional burn out or an enforced distance, undermines the relationship and the child may feel rejected and unloved. When this happens, there is potential for the parent to feel threatened and for the relationship to break down. We can see this in Shelley's story (above); the Dystopian Triangle is a warning to practitioners and parents that when unwritten permission is absent and there is a dearth of Professional Love, the consequences for the child are damaging. The Triangle of Love is only a meta-normative ideal type, but it is what that "permission" implicitly seeks to approximate.

Figure 1: Thinking about 'Professional Love' about here

\section{A prospectus for developing Professional Love}

- The first step in the process of 'Thinking about Professional Love' is for a practitioner to have mastered the emotional resilience and possess the intellectual capacity to become self-aware. When s/he is able to understand how to step outside of his/her own personal frame of reference s/he becomes available to reflect upon the consequences of his/her actions and interactions with others, i.e the child and/or parent. This first step in itself will only come about with continual reflection and as part of an ongoing attempt to be reflexive.

○ Here I apply Etherington's (2007) position to this practical application. I suggest the use of a reflective journal will support the notion of "including our "selves" in the process of understanding. Like Etherington (2007) I believe that 'to display in our writing/conversations the interactions between ourselves and others... our work can be understood, not only in terms of what we have discovered, but how we have discovered it' (p.601). In tandem with ideas put forward by Pettersen (2012), I suggest a focus on a model of reciprocity that takes account of opportunities for dialogue about context and practical application to allow for practitioners to develop maturity of understanding. Ideally, I suggest a radical rethink of early years 'supervision' practice (DfE, 2017). The model proposed by Elfer (2012) that attends not only to child protection and safeguarding, but which properly supports practitioners to enter 
into a dialogue with a manager about the emotional burden of working intensively with young children and families to help them to think more clearly about their feelings, is also necessary here.

- Step two is to de-centre; to be compelled to act for the good of the other person. In doing so the practitioner needs to shift his/her thinking away from him/her self and his/her own needs, and instead to become completely absorbed in thinking about and acting with the needs of the other person in mind, in a completely non-judgmental way.

- Step three is when the practitioner is able to be completely immersed in the needs of the 'other' by investing a level of emotional intimacy into the relationship -rather than to distance his/her self from the child and/or parent.

- Step four is for the practitioner to build a gradual, authentic, reciprocal relationship with the child and parent. It is this reciprocal relationship which determines the level of acceptance and trust between the child and the practitioner but also between the practitioner and the parent which constitutes the often unsaid 'permission' to continue to build the relationship.

- When the practitioner has built an enduring mutual relationship with the young child with whom s/he has formed a close, affectionate bond, developed over many hours, days, weeks, months or even years of the child's attendance at the early years setting, then it is likely that the practitioner will have come to love the child in this professional context.

\section{Conclusion}

I have presented a model of Professional Love to appropriately enable early years practitioners to develop their own set of principles, policies and practices; a pedagogy of love which professionals are able to draw upon to respond to the minutiae of the many and varied lived experiences of young children whatever their socio-cultural context. This model offers continuity of practice while still responding to socio-culturally formed needs and the continually evolving experiences of each child within the context of his or her own family and community; locally, nationally and globally. In this regard Professional Love, as I have characterised it, does not attempt to apply a universal definition of love [or intimacy or care], 
into a criteria checklist. Rather, it provides an opportunity for critical reflection and adaptation which takes account of these fleeting, yet crucial exchanges which occur between young children and their professional primary caregivers. Thus, each setting can generate its own phenomenology of Professional Love. In practical terms this should lead to the creation of policies and procedures which give confidence to caregivers about cuddling young children without fear of reprisal.

As Shin (2015) argues, 'students do not learn to care simply by being told how to care' (p. 506). There is a need to model the principles of professionally loving practice as opposed to inventing inappropriate tick lists. In a Professional Love-orientated setting, there ought to be evidence of critical reflection and thoughtful dialogue between professionals and with parents, so that there is ample opportunity to deconstruct the everyday lived experiences of young children which include intimate care routines such as wiping noses and changing nappies.

To conclude, this paper has:

- Grounded an iterative but clear characterisation of Professional Love on Noddings's (2003) notion of an 'ethic of care'; it has emphasised the mutual beneficence and reciprocal needs-satiation which form the basis for the practice of Professional Love, rejecting an altruistic model of self-sacrifice and arguing that Professional Love needs to be conceived of as care-sharing, not care-giving.

- Argued that attachment theory supports and reasserts the need for Professional Love to be inculcated into early years discourse; it simultaneously argues that attachment theory's limitation - insofar as it crudely constraints the model of carer to the primary home one (usually the mother) and thus negates the complex of social interactions which influence a child's ability to maintain meaningful relationships - paradoxically also supports a call for Professional Love. This is because Professional Love as a concept values the role/s played by practitioners, cultures, peers and so on.

- Claimed that the devaluation of Professional Love in the formal and informal lexicon of early years education constrains the development, growth and learning of the children practitioners work with; Professional Love is debunked by contemporary policy languages and by the normative reductionism which sees early years work in general as a case of "just" wiping noses.

- Highlighted that Professional Love tends to be encouraged in principle but (over) regulated in practice, and that the absence in the English frameworks for early years 
education of discussion around Professional Love drives an informalisation of practice. This is one whereby practitioners intuit that attachment and reciprocity are vital but they practice this outside of the official and formal framework of best practice.

- Provided a model for 'thinking about Professional Love' which posits that when reciprocity exists, and as the relationship deepens, then the compulsion to care, together with the capacity to de-centre and invest a level of emotional intimacy into the relationship, can it be characterised as Professional Love. This model also breaks down a prospectus for the individual practitioner which breaks down steps of reflexive awareness building for developing Professionally Loving practice.

- Countered this injunction for the individual practitioner to "develop Professional Love" on his/her own by discussing policy frameworks and interventions to date and arguing that for individual subjects to practice Professional Love, support has to be offered by policymakers which facilitates reflection on the concept and its practical ramifications.

Undoubtedly it is the role of the early years manager to provide supervisory support to practitioners who work in these emotionally complex roles (Elfer, 2012). Yet, I maintain that Noddings's (2003) ethic of care foregrounds the significance for those who work in a caring role with children to be both intellectually and emotionally capable as a core requirement. It is the responsibility of the emotionally resilient practitioner to recognise the challenges this professional closeness brings to their relationship with the child and the tensions it raises for others, i.e. parents, colleagues, managers, inspectors. But the development of that emotional resilience can be enabled and unlocked by managers and policymakers. Professional Love is a legitimate discursive interlocutor which recognises and affirms the existence and importance of loving relationships between professionals and young children, distinguishable from models of familial love; this paper opens up a pedagogic space in which to critically evaluate love, care and intimacy as part of an authentic dialogue between practitioners, parents, policymakers and multi-disciplinary professionals. This includes those in initial training and those in continuing professional development as well as those working with alternative theoretical frameworks in the fields of neuroscience, philosophy, anthropology, psychology, psychoanalysis and beyond.

\section{Endnote:}

Some - or indeed, many - who read this paper may think: 'But that's what I've always done!' or: 'That's merely a description of good practice, call it what you will!'. If that is so, then the effort will not have been wasted because the paper may help confirm and enhance good 
professional practice, perhaps adding some useful names to its emotional glossary. But for those who find the ideas too discomfiting, I hope that the paper will give a stir to their discomfort around love and intimacy in early years settings.

\section{References}

Ainsworth, M. D. S. 1963. The development of infant-mother interaction among the Ganda. In B. M. Foss (Ed.), Determinants of infant behavior (pp. 67-104). New York: Wiley.

Ainsworth, M. D. S. 1967. Infancy in Uganda: Infant care and the growth of love. Baltimore: Johns Hopkins University Press.

Aslanian, T. K. 2015. Getting behind discourses of love, care and maternalism in early childhood education. Contemporary Issues in Early Childhood, 16(2), 153-165.

Bigelow KM and Morris EK. 2001. John B. Watson's advice on child rearing: Some historical context. Behavioral Development Bulletin 1(Fall 2001): 26-30

Bion, W. 1962. Learning from experience, London: Heinemann

Bloch M.N. 1992. Critical perspectives on the historical relationship between child development and early childhood education research. In: Kessler S and Swadener BB. Eds. Reconceptualizing the Early Childhood Curriculum. New York: Teachers College Press, (pp.3-20)

Bowlby, J. 1953. Child care and the Growth of Love Middlesex: Penguin

Bowlby, J. 1969. Attachment and Loss: Volume 1. Attachment, New York, Basic Books.

Bowlby, J. 1973. Attachment and Loss: Volume 2. Separation: Anxiety and Anger, New York, Basic Books.

Bowlby, J. 1988. A Secure Base: Parent-Child Attachment and Healthy Human Development, New York, Basic Books.

Cassidy, J. 2008. The Nature of the Child's Ties. In J. Cassidy and P. Shaver, Cassidy. Eds. Handbook of Attachment: Theory, Research and Clinical Application $2^{\text {nd }}$ edn. pp. 3-22. London: The Guildford Press.

Cousins, S. 2017. Practitioners' constructions of love in early childhood education and care. International Journal of Early Years Education, 25 (1), 16-29

Dahlberg, G., P. Moss, and A. Pence. 2007. Beyond Quality in Early Childhood Education and Care: Languages of Evaluation. 2nd ed. London: Falmer Press

Darder, A. 2002. Reinventing Paulo Freire: A Pedagogy of Love. Boulder: Westview Press

David, T., Goouch, K., Powell, S. and Abbott, L. 2003. Birth to Three Matters: A Review of the Literature. London, UK: Department for Education and Skills 
Department for Children Schools and Families. 2008. The early years foundation stage: setting the standards for learning, development and care for children from birth to five, London: DCSF

Degotardi, S. and Pearson, E. 2009. Relationship Theory in the Nursery: attachment and beyond, Contemporary Issues in Early Childhood, 10 (2), 144-145.

Department for Education. 2012. Statutory framework for the early years foundation stage: Setting the standards for learning, development and care for children from birth to five. London: Department for Education.

Department for Education. 2014. Statutory framework for the early years foundation stage: Setting the standards for learning, development and care for children from birth to five. London: Department for Education.

Department for Education. 2017. Statutory framework for the early years foundation stage: Setting the standards for learning, development and care for children from birth to five. London: Department for Education.

Dolby, R. Hughes, E. and Friezer, B. 2014. Playspaces: Educators, Parents and Toddlers In L Harrison and J Sumsion (Eds). Lived Spaces of Infant-Toddler Education and Care Exploring Diverse Perspectives on Theory, Research, Practice and Policy. (pp.89-102). International Perspectives on Early Childhood Education and Development Series. Springer Publishing. Dordrecht Heidelberg New York London

Elfer, P. 2006. Exploring children's expressions of attachment in nursery, European Early Childhood Education Research Journal, 14, (2). pp 81-95

Elfer. P. 2012. Emotion in nursery work: Work Discussion as a model of critical professional reflection, Early Years, 32(2), 129-141

Elfer. P. and Page, J. 2015. Pedagogy with babies: perspectives of eight nursery managers. Early Child Development and Care, 185, (11-12),1762-1782

Etherington, K. 2007. Ethical research in reflexive relationships, Qualitative Inquiry, 13 (5), pp 599-616.

Ferguson, 2017. How children become invisible in child protection work: findings from research into day-to-day social work practice British Journal of Social Work 47, 1007-1023

Gilligan,C. 1982. In a different voice: psychological theory and women's development. Cambridge, Massachusetts: Harvard University Press.

Goldstein, L. 1998. More than gentle smiles and warm hugs: applying the ethic of care to early childhood education, Journal of Research in Childhood Education, Spring/Summer 12, (2) 244-261

Gratzke, M. 2015. 'Love is what people say it is'. Gratzke Inaugural Speech. 27 April 2015. Love Research Hull https://archive.org/details/MichaelGratzkeInauguralHull2015 Accessed online 1 October 2017

Kawamura , K.M.2013 "An Interview with Nel Noddings, PhD", Cross Cultural Management: An International Journal, $20 \quad$ (2) $\underline{\text { https://doi- }}$ 
org.ezproxy.brighton.ac.uk/10.1108/ccm.2013.13620baa.004 Accessed online: 1 October 2017

Lally, J. R. 1995. The impact of childcare policies on infant/toddler identity formation. Young Children, 51(1), 58-67.

Määttä, K., \& Uusiautti, S. 2011. Pedagogical love and good teacherhood. In Education, 17(2) 29-41

Määttä, K., \& Uusiautti, S. 2012a. How do the Finnish family policy and early education system support the well-being, happiness, and success of families and children? Early Child Development and Care, 182(3-4), 291-298.

Määttä, K., \& Uusiautti, S. 2012b. How to raise children to be good people? Analytic Teaching and Philosophical Praxis, 33(1), 83-91.

Määttä, K., \& Uusiautti, S. 2012c. Parental love -Irreplaceable for children's well-being. Global Journal of Human Social Sciences, 12(10), 1-8.

Määttä, K., \& Uusiautti, S. 2012d. Pedagogical authority and pedagogical love - connected or incompatible? International Journal of Whole Schooling, 8(1), 21-39.

Määttä, K., \& Uusiautti, S. 2013. Many faces of love. Rotterdam: Sense Publishers

McHale J.P. 2007. "When infants grow up in multiperson relationship systems". Infant Mental Health Journal 28 (4), 370-92

Noddings, N. 1984. Caring: A feminine approach to ethics and moral education, Berkeley, CA: University of California Press

Noddings, N. 2003. Caring: A feminine approach to ethics and moral education, 2nd edn. Berkeley, CA: University of California Press

Nutbrown, C. 1996. Respectful Educators - Capable Learners: Children's Rights and Early Education. London: Paul Chapman Publishing

Nutbrown, C. 2012. Foundations for Quality: Final Report. London: Department for Education

Page, J. 2011. Do mothers want professional carers to love their babies? Journal of Early Childhood Research. 9, (3) 310-323

Page, J. 2013a. Will the 'good' [working] mother please stand up?: Professional and maternal concerns about education, care and love. Gender and Education, 25 (5) 548-563

Page, J. 2013b. Childcare Choices and Voices: using interpreted narratives and thematic meaning-making to analyse mothers' life histories. International Journal of Qualitative Studies in Education, 27,(7) 850-876.

Page, J. 2013c. Permission to love them.... but not too much, In Page, J. Clare, A. and Nutbrown, C. Working with Babies and Children: From birth to three. 2nd edn. (pp. 192196). London: Sage. 
Page, J. 2014. Developing "professional love" in early childhood settings, In L Harrison and J Sumsion (Eds) (2014). Lived Spaces of Infant-Toddler Education and Care Exploring Diverse Perspectives on Theory, Research, Practice and Policy. (pp.119-130). International Perspectives on Early Childhood Education and Development Series. (pp .119-130) Springer Publishing Dordrecht Heidelberg New York London

Page, J. 2016. Educators' perspectives on attachment and professional love in early years settings in England. In E. J White and C. Dalli (Eds) Under three year-olds in policy and practice. Policy and pedagogy with under-three-year-olds: Cross-disciplinary insights and innovations for educational research with very young children Series. (pp 131-142) Springer Publishing

Page, J. 2017. Reframing infant-toddler pedagogy through a lens of professional love: Exploring narratives of professional practice in early childhood settings in England. Contemporary Issues in Early Childhood, 18, (4), 387-399

Page, J., and Elfer, P. 2013. The emotional complexity of attachment interactions in nursery, European Early Childhood Education Research Journal 21 (4) 553-567

Pettersen, T. 2011. The Ethics of Care: Normative Structures and Empirical Implications Health Care Analysis 19, 51-64

Pettersen, T. 2012. Conceptions of Care: Altruism, Feminism, and Mature Care Hypatia 27, (2) 366-389

Powell, S. and Goouch, K. 2012. Whose hand rocks the cradle? Parallel discourses in the baby room. Early Years, 32, (2), 113-127

Quinn, N. and Mageo, J. 2013 (Eds). Cultural Perspectives on a Western Theory. New York: Palgrave Macmillan

Rockel, J. 2009. A pedagogy of care: Moving beyond the margins of managing work and minding babies. Australian Journal of Early Childhood, 34 (3), 1-8.

Shin, M. 2015. Enacting caring pedagogy in the infant classroom, Early Child Development and Care, 185 (3), 496-508.

Stern, D. N. 2000. The interpersonal world of the infant. New York: Basic Books.

Uusiautti, S and Määttä, K. 2013. Love-Based leadership in early childhood education. Journal of Education Culture and Society 1, 109-120

Watson, J. B. 1928. Psychological Care of Infant and Child. New York: W.W. Norton Company, Inc

White, E.J. 2016. Introducing dialogic pedagogy: Provocations for the early years, London: Routledge 